慶應義塾大学学術情報リポジトリ

Keio Associated Repository of Academic resouces

\begin{tabular}{|c|l|}
\hline Title & $\begin{array}{l}\text { Gene expression associated with the decrease in malignant phenotype of human liver cancer } \\
\text { cells following stimulation with a histone deacetylase inhibitor. }\end{array}$ \\
\hline Sub Title & ヒストン脱アセチル化酵素阻害剤刺激によるヒト肝癌細胞の悪性度低下に伴う遺伝子発現 \\
\hline Author & 若林, 寛二(Wakabayashi, Kanji) \\
\hline Publisher & 慶應医学会 \\
\hline Publication year & 2005 \\
\hline Jtitle & 慶應医学 (Journal of the Keio Medical Society). Vol.82, No.2 (2005. 6),p.11- \\
\hline JaLC DOI & \\
\hline Abstract & \\
\hline Notes & 号外 \\
\hline Genre & Journal Article \\
\hline URL & https://koara.lib.keio.ac.jp/xoonips/modules/xoonips/detail.php?koara_id=AN00069296-2005060 \\
\hline
\end{tabular}

慶應義塾大学学術情報リポジトリ(KOARA)に掲載されているコンテンッの著作権は、それぞれの著作者、学会または出版社/発行者に帰属し、その権利は著作権法によって 保護されています。引用にあたっては、著作権法を遵守してご利用ください。

The copyrights of content available on the KeiO Associated Repository of Academic resources (KOARA) belong to the respective authors, academic societies, or publishers/issuers, and these rights are protected by the Japanese Copyright Act. When quoting the content, please follow the Japanese copyright act. 


\section{Gene expression associated with the decrease in malignant phenotype of human liver cancer cells following stimulation with a histone deacetylase inhibitor.}

（ヒストン脱アセチル化酵素阻害剂刺激によるヒト肝癌細胞の悪性度低下に伴う遺伝子発現）

若林寛 二

\section{内容の要旨}

酪酸は短鎖脂肪酸の一つであり、生体内では消化管内で自然に形成 されることが知られている。酪酸は各種癌細胞に対しアポトーシスや 分化誘導作用を有することが報告されている。酪酸はヒストン脱アセ チル化酵素阻害剤の一つであり、クロマチンのかたまりを解除し、転 写活性を高めることが考えられている。酪酸は肝癌細胞に対して高濃 度では一部の細胞にアポトーシスを、低濃度では悪性度低下を生じる ことを報告してきた。低濃度ではアルブミンの産生がえ進し、 $\alpha$-feto proteinの産生が低下し、ソフトアガー内での足場非依存性增殖は抑制 される。しかし、その機序についてはいまだ不明な点が多い。そこで、 ヒト肝癌細胞株HCC-Tを用いてアポトーシスが生じない低濃度（2 $\mathrm{mM}$ ）で酪酸を添加培養し、早期の段階での遺伝子発現変化につき検 討した。

酪酸刺激により HCC-Tは細胞周期において G0/G1期での停止し、

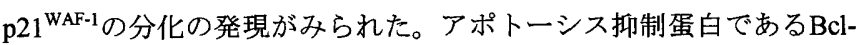
2、Bcl-XLは分化誘導早期において発現は増加し、Bcl-2ファミリー蛋 白で発生分化初期に発現する Mcl-1/EATも発現は上昇した。一方アポ トーシス促進蛋白であるBAXは変化がみられなかった。うしたアポ トーシス抑制蛋白の発現が増加することにより、アポトーシスを抑制 しながら細胞周期を $\mathrm{G} 0 / \mathrm{G} 1$ 期において停止し、悪性度低下へと進んで いくもので、細胞分化の誘導の一種とも考えられる。

どのような遺伝子発現が変化し、悪性度低下に関わっているのかを 追求することが、今後遺伝子を標的とした肝癌治療に有用となる可能 性がある。そこで、 differential displayとcDNA expression arrayにて誘導 初期の段階での遺伝子変化を検討した。Differential display法ではラミ ニン、ケラチン18といった細胞骨格にかかわる遺伝子の発現上昇がみ られた。cDNA expression arrayでは、Western blotでの解析に一致して、 $\mathrm{Mcl}-1 / \mathrm{EAT}$ と $21^{\mathrm{WAF}-1}$ の発現増加がみられ、 $\mathrm{p} 21^{\mathrm{WAF}-1}$ の上流にて変化す るIRF-1の発現も上昇が確認された。

生体内での酪酸の産生增加や、悪性度低下誘導課程でみられた遺伝 子を操作することにより、肝癌治療への応用が期待される。

\section{論文審査の要旨}

酪酸は肝癌細胞に対して高濃度では一部の細胞にアポトーシスを 誘導し、低濃度では悪性度を低下させる。酪酸刺激によりどのよう な遺伝子発現が変化し、どのような蛋白が誘導され、悪性度低下に 関わっているのかを追求することは、将来新たな肝細胞癌の発生予 防法や治療方法につながる可能性がある。本研究では肝癌細胞株を 酪酸で刺激し、早期の段階での遺伝子発現変化をdifferential display法 とcDNA expression arrayにて検討した。Differential display法ではラミ ニン, ケラチン 18 ケつの細胞骨格に関わる遺伝子発現が上昇し, 細胞の形態変化が悪性度の低下に関わる一つの重要な因子であるこ とが示唆された。cDNA expression arrayでは細胞周期に関わるp $21^{\text {WAF-1 }}$ 遺伝子や細胞骨格に関わるRho E遺伝子の発現変化がみられた。ま た、分化マーカーであるELF-1やMcl-1/EATの発現が上昇し、イン ターフェロン関連遺伝子IRF-1、STAT2、STAT3の発現上昇が認めら れ、酪酸がインターフェロンと類似した作用を有することが示唆さ れた。

審査では、まず何故肝癌細胞株としてHCC-Tを用いたのか、他の 細胞株についても検討しなかったのか、より強力な分化誘導剈であ るトリコスタチンAによる作用については検討されているのか、と の質問があった。これに対してHCC-Tは当研究室で樹立された細胞 株で，これまで酪酸刺激による悪性度の低下に関するデーターがあ り, 肝癌細胞株の中ではもっとも酪酸刺激による細胞增殖抑制効果 がはっきりしているため, 今回の研究に適していると回答された。 トリコスタチンAによる肝癌細胞株の增殖抑制作用については確認 しているが、これまで酪酸でのデーターの方が多いため、differential displayとcDNA expression arrayは酪酸による刺激で検討したと回答さ れた。

また、 differential displayとcDNA expression arrayの結果については RT-PCRやNorthern blotでの検討、Western blotによる蛋白レベルでの 発現確認がなされているかなど、再現性の有無を指摘された。これ に対して、今回特に注目された遺伝子発現についてWestern blotによ り確認したと回答された。

さらに、 differential displayとcDNA expression arrayで発現変化がみ られた個々の遺伝子について、より梁く現象との関連について検討 されるべきであると指摘があった。

本研究は今後検討されるべき課題を残しているが、酪酸による肝 癌細胞の悪性度低下に伴う変化を蛋白、遺伝子のレベルで検討した 点が有意義な研究であると評価された。

論文審査担当者
主査 内科学 日比 紀文
学 北島 政樹 病理学 坂元 烹宇
先端医科学 河上 裕
学力確認担当者 :
審查委員長 : 北島 政樹

試問日：平成17年 3 月 2 日 